\title{
Analysis of monthly, seasonal and annual air temperature variability trends in Junagadh (Saurashtra region) of Gujarat
}

\section{BHAVIN RAM, S.S. CHINCHORKAR, M.S. KHARDIWAR AND F.G. SAYYAD}

Received : 08.12.2014; Revised : 13.02.2015; Accepted : 27.02.2015

See end of the Paper for authors' affiliation

Correspondence to :

BHAVIN RAM

Anand Agricultural University, Muvaliya Farm, DAHOD (GUJARAT) INDIA

Email : bhavinram@gmail.com
- ABSTRACT : Climatic change is one of the most important issues of present times, therefore, world-wide interest in global warming and climate change has led to numerous trend detection studies. Anthropogenic interference in the environment is one of the greatest causes of the process of climatic change in several regions of the world. This study focuses on the variability and trends of the mean annual, seasonal and monthly surface air temperature in Junagadh (Saurashtra region) of Gujarat, during the period 1980-2011. This study investigated monthly, seasonal and annual climatic variability in Junagadh (Saurashtra region) of Gujarat based on mean maximum, mean minimum and mean air temperatures. One of the main results of this study was the confirmation of a significant warming trend in average temperatures in Junagadh (Saurashtra region) of Gujarat. Analysis of maximum and minimum temperatures revealed a warming trend for the annual and all seasonal series. The warming trend for the summer and winter seasons was statistically significant at $\mathrm{P}<0.01$ level with a rate of increase of $0.006 \mathrm{C} /$ year and less $0.055 \mathrm{C} /$ year. The air temperature time series were analyzed, so that the variability and trends can be described.

- KEY WORDS : Air temperature, Climate change, Mann-Kendall test, Trends

- HOW TO CITE THIS PAPER : Ram, Bhavin, Chinchorkar, S.S., Khardiwar, M.S. and Sayyad, F.G. (2015). Analysis of monthly, seasonal and annual air temperature variability trends in Junagadh (Saurashtra region) of Gujarat. Internat. J. Agric. Engg., 8(1) : 39-46. 